\title{
Influence of Social Media on Democratic Governance in Nigeria
}

\author{
BABALEYE, Taye $^{1^{*}}$, IBITOYE Pius ${ }^{2}$, Odorume, Akpobo Emokiniovo ${ }^{3}$

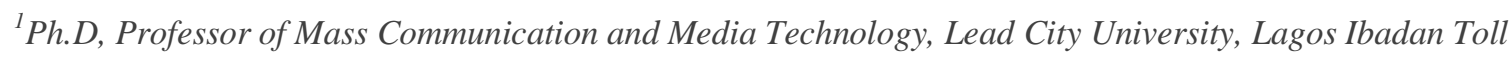 \\ Gate Area, P.O.Box 30678 Secretariat, Ibadan. Nigeria \\ ${ }^{2}$ Department of Media and Communication Studies, Afe Babalola University, Ado-Ekiti, Nigeria \\ ${ }^{3}$ Department of Mass Communication, Oduduwa University, Ile-Ife, Osun State, Nigeria
}

*Corresponding Author: BABALEYE, Taye, Ph.D, Professor of Mass Communication and Media Technology, Lead City University, Lagos Ibadan Toll Gate Area, P.O.Box 30678 Secretariat, Ibadan. Nigeria

\begin{abstract}
Over the years, many things have been put in place to achieve a sustainable democratic rule in Nigeria. The rule of law and good information management are sacrosanct to the success of any democratic government. One popular channel used by the polity to address pertinent political issues these days is the social media. The social media which are a fall out of the new media-the internet, consist of such platforms as Facebook, Twitter, Whatsapp, Instagram etc. under which citizens post messages on issues of corruption, terrorism, insurgency, economic mismanagement and poor governance which are key factors affecting the society. Their contents are user generated and do not go through the scrutiny of the gate keeper as is the practice in the traditional media. In comparison to the traditional media. Social media are used as free for all criticism platforms to the key players and other stakeholders in Nigeria's fragile democracy. Lately, in order to curb the abuse of social media powers the National Assembly began debates on the introduction of a bill stipulating death penalty as punishment for perpetrators of fake news aimed at denigrating high ranking political office holders in the Executive, the Legislature and the Judiciary. Though the proposed bill has received all round condemnation, it is however an evidence of the pains being afflicted by negative and destructive reports on social media against Nigerian politicians. The use of abusive words, deliberate falsehood without any respect for the ethics of journalism practice is a major problem that government is contending with under the democratic rule in Nigeria. This article examines the role played by the social media to enhance democratic rule in the country. A population of 200 respondents from both staff and students of Ekiti State University, Ado-Ekiti was used to gather data. The article was framed on the uses and gratification and dependency theories. The Survey research method was used to determine the influence of social media on democratic rule in Nigeria. It was found that majority of respondents (95\%) believed that social media, in spite of their excesses play positive roles to ensure and enhance durable democracy in Nigeria.
\end{abstract}

Keywords: Democratic principles, Social Media, Traditional Media, Democratic dispensation

\section{INTRODUCTION}

Democracy is generally defined as "the government of the people by the people and for the people. A government in which the supreme power is vested in the people and exercised by them directly or indirectly through a system of representation usually involving periodically held free elections. In any democracy, the press helps in actualizing and making known to the public, the affairs of the government by serving as the watchdog of the society. Democracy is a system of government in which the people of a country can vote to elect their representatives and are involved in making decisions about its affairs, typically by voting to elect representatives to a parliament or similar assembly, as defined by the Oxford English Dictionary $8^{\text {th }}$ edition (2010).

According to Miroslav (2005), in real democracy everybody must be allowed to participate in decision making (direct democracy). It must be a pluralistic system that is as decentralized as possible (territorially and minority wise). All decisions pertaining only to a given group (minority) must be done solely within that group. To be able to achieve real democracy, at large (i.e., affecting the whole society or most of it) authoritative (top-down) structures in which decisions are made solely by commands from a single center have to be removed from the society. 
Democracy is built on the equality of citizens; the freedom of these citizens to associate with one another for the realization of their ideals and the defense and promotion of their interests; and the freedom of these citizens to choose between the different political platforms of various political parties and candidates, and see to the actualization of the platforms they have voted for, if their choices win.

However, in Nigeria, people have effectively been disenfranchised by their own circumstances on the one hand, and their leaders' perfidy on the other. As a result, Nigeria is approaching a situation where democracy is being practiced without democrats and elections are being conducted with scant regard for the electorate. The government does not respect the ballot and the price of protecting it is too high for the people to pay; but the bullet, once universally feared, is now generally out of fashion.Asemah (2011) says constitutional democracy is the basis for good governance as good governance is the antidote to corruption. Universally speaking, democracy as a form of government has had a long-term relationship with the mass media

The mass media is a diversified collection of media technologies that reach a large audience via mass communication. The technology through which this communication takes place includes a variety of outlets. Broadcast media transmit information electronically, via such media as film, radio, recorded music, or television. Digital media comprises both Internet and mobile mass communication. Internet media comprise such services as email, social media sites, websites, and Internet-based radio and television.

Print media transmit information via physical objects, such as books, comics, magazines, newspapers, or pamphlets. Outdoor media transmit information via such media as billboards; blimps; flying billboards (signs in tow of airplanes); placards placed inside and outside of buses, commercial buildings, shops, sports stadiums, subway cars, or trains; signs; or skywriting (Pieter, 2008).

Nigeria mass media history dates back to when "IweIroyin fun awonomo Yoruba atiEgba" was established in 1859 by Rev. Henry Townsend. Its major aim at the time is to influence the traditional government they found in Egbaland whose mode of operation did not conform to their idea of "good" governance. More newspaper publications were established and used by nationalists such as Herbert Macauley, DrNnamdiAzikiwe and Chief ObafemiAwolowo to fight for freedom until Nigeria gained independence in 1960.

The mass media is framed around journalism. Journalism is the discipline of collecting, analyzing, verifying and presenting information regarding current events, trends, issues and people. Those who practice journalism are known as journalists (Pieter, ibid). Journalism is basically the process of identifying, gathering, packaging and presentation of information as news to people in the society. A typical media personal can be regarded as an information manager. This is because a journalist is exposed to different kinds of information on a daily basis. As such, the journalist has the responsibility of ensuring that the information being reported as news will have more positive than negative impact on the society even though they have the right to truthful information. Recent trend in journalism and reportage on the society has revealed a drop in the social responsibility duty of the journalist. This article is focused on the social media, information management and democratic rule in Nigeria.

The rapid development of both technology and knowledge make 'social media' to change at a rapid rate, as new websites and online contents appear each day. The Oxford Dictionary (2011) defines social media as 'websites and applications used for social networking'. Kietzmann (2011) also defined the social media as "interactive platforms which individuals and communities create and share user-generated content". Social media technologies take on different forms including magazines, Internet forums, weblogs, social blogs, micro-blogging, wikis, social networks, podcasts, photographs or pictures, video, rating and social bookmarking. These Social Media platforms differ according to the extent to which they focus on some of all of seven functional building blocks of the society namely identity, conversations, sharing, presence, relationships, reputation, and groups (Jacobs, 2013).

Social media platforms and related technologies have enabled a revolution in user-generated content, global community and the publishing of consumer opinion, now uniformly tagged as social media. Both the government and the governed to express their minds about the issues that affect the society 
can use the social media platforms to do so. During the last democratic administration, interviewers used Twitter a social media platform as a means of getting Nigerians to ask ex-president Goodluck Jonathan questions about certain decisions and policies of his administration during his quarterly presidential media chat in 2013. It can be said that the social media, irrespective of the access to it, can be used as a platform by which the government and the governed to interact with each other. It is used by the people not only to maintain peace in the society but also to express their minds and views on issues so that a compromise can be reached for the betterment of the Nigerian society.

\section{Social Media AND Citizen REPORTAGE IN Nigeria}

The social media or in other words the new media according to Flew (2008:4) sprang up following the development of the internet, which "brings together computing and information technologies, communication networks and media contents." This in accordance to Flews' view, when talking about the internet, the major things to carefully study includes the technology involved i.e. computer technicalities and the content, meaning the information; in-between these two occurs interaction. The social media therefore, have social impacts through the interaction that exists between human beings and the social media. Social media platform is growing day in day out in faster dissemination of news, events and all happenings in general. It is making the job of reporters easier and faster. Media houses in Nigeria today have two or more social media platforms they use in relating with their audiences because the world is turning into a global village. Even skilled and unskilled reporters have their ways of reporting news and getting news events. According to Marshall (2005),contemporary studies on the impacts of technology on journalism have therefore, identified serious threats to the traditional roles of journalists by people without news reporting background or training that contributes news items to the mainstream media.

The Nigerian print media, which has always been in the forefront of the country's political struggles before and after the country's independence is experiencing a boost from citizen reporters who provide an alternative source of news to them, which had over the years suffered different forms of repression from successive Nigeria governments. Although citizen reporters do not contribute news directly to print media (but exclusively to digital media) the migration of most of Nigerian newspapers and magazines online and the ever increasing Nigerian citizen news websites have tremendously impacted the process on news delivery by the Nigerian print media (Aborishade, 2012).

Many citizen reporters use social media for promotion, research work, interacting with the audience and reporting the affairs of the government. The use of social media as reporters brings a sense of belonging to their audience. It can bring the reporter closer to the people since the internet nature of communication is such that individuals are more likely to source information from each other rather than traditional news agencies. Thus, information dissemination has become decentralized and news reporting has become deregulated.

Advancement in technology brings major impacts on information management in a democratic rule. Many skilled and unskilled reporters are expending their investments in information technology and specifically the internet, and are actively promoting internet in Nigeria and the world at large, (AlNuaimy, Zhang \& Noble 2001). Baran \& Davis, (2000) further argue that the media have impacts, positing that scholars can consider how the media industries came up from the historical perspective, and use current developments, so that they can interpret what obtains at the moment.' Gillmor (2004) explained how individuals without journalism background or training can produce news using blogs, chat groups, e-mail, and many other news gathering, reporting, and distribution tools. The author challenges journalists, newsmakers (politicians, business owners and celebrities) and marketers who promote them (PR organizations) to wake up to the realities of the new journalism and shift from control to engagement. In particular, Gillmor challenged traditional journalists to be more prepared to change and operate within the dynamics of the new era or be rendered irrelevant in the business of newsgathering, reporting, and distribution.

Jost and Hipolit (2006) observe that social media platforms reduce the influence of the elites and institutions, thus allowing wider public participation and greater interactivity. Jost and Hipolit (ibid) stated further that the increasing numbers of bloggers who use new technologies and media modalities in digital technologies to contribute news, images, and videos without journalism training is changing politics, business, information management, and popular culture for the better. It was almost the end of the twentieth century when internet was introduced for the common person and now it has been 
integrated in everyone's life. It has proved itself a very useful invention in different ways and the most interesting thing that became available through internet to the public is social media. Now the use of social media is not limited to discussing family events, and sharing photos and videos, it can actually create history and make a difference in the real world (Kolawole, 2015). During the 2019 general elections in Nigeria social media was used by the different political parties and their candidates to campaign for the citizen's votes and sympathy. Journalists use social media to inform the public about the happenings of the elections through the various social media platforms that Nigerians in diasporas can access news about the elections as it unfolds. Social media brings us closer to government and the rest of the world at large. It suffices to say that social media platforms are democratic social networks.

\section{Statement of the Problem}

The press was instrumental to the attainment of Nigeria independence in1960. At that time, the press was vocal but it still maintained decorum. The press was not using its power to run down any ethnic group against the other, it was fighting for the liberation of the oppressed. However, under the present democratic dispensation, the use of social media by the citizens calls for concern in comparison to the traditional media. With the social media, caution is thrown overboard on the extent of criticism that can be leveled against the government and the ruling political party. This is not always the case with the traditional media where there are gatekeepers who can impose self-censorship. This study therefore seeks to examine the use of social media under the present democratic dispensation in Nigeria, especially before and immediately after the 2019 general elections.

\subsection{Objectives of the Study}

- To find out the role of the social media in upholding democracy in Nigeria.

- To know the effect of social media criticisms of the government and the ruling political party on democratic governance in Nigeria.

\subsection{Research Questions}

- What role has social media played in upholding democracy in Nigeria?

- Does the social media criticism of the government and the ruling political party have any effect on democratic governance in Nigeria?

\subsection{Media Dependency Theory}

Sandra Ball-Roach and Malvin De Fleur propounded dependency theory in 1976. The explanation of the relationship between the contents of the mass media, the nature of society, and the communication behavior of the audiences is called dependency theory. People are dependent on the media for their information needs. People in all societies need information in order to make decisions about such matters as food, shelter, employment, transportation, political issues, entertainment, and other aspects of family life. In traditional societies, people tend to pursue similar ways of life and are linked by word of mouth networks of extended families, deeply established friendships long-term neighbors, and other social ties from which they obtain the information that they need.

In urban industrialized societies, populations are composed of unlike people brought together through internal migrations and immigrants from outside. They are greatly differentiated by such factors as race, ethnicity, occupational specialization, and economic class (Anaeto, Onabajo and Osifeso, 2008).This theory was used to explain people's perception of what they can get from the media rather than what the media can get from them. Many people depend solely on the media to get news and gather information online rather than the traditional media.

\subsection{Uses and Gratification Theory}

The theory was propounded by Blumler and Katz in 1974. Blumler and Katz Uses and Gratification Theory suggests that media users play an active role in choosing and using the media. Users take an active part in the communication process and are goal oriented in their media use. The theorists say that a media user seeks out a media source that best fulfills the needs of the user. Uses and Gratification Theory assumes that the users have alternatives to satisfy their needs from any media of their choice. The Uses and Gratification theory is linked to this study from the perspective that people 
use the online newspaper and social media platforms to gather information and share their thoughts about governance and generally happenings around the world without stress. People use the media to satisfy their needs and gratification for news, knowledge, entertainment and other ideas that can be useful to them.

\section{RESEARCH METHODOLOGY}

The Research Design: The Research design for this study was the survey. It involves the use of quantitative questionnaire to gather data needed from the respondents. Items in the questionnaire were drawn from the research questions to enable respondents give detailed and wider response to the research questions that eventually helped in determining the outcome of the study.

Study Population: The population for this study inluded users of the different social media platforms in Ekiti State University, Ado Ekiti.

Sample Size and Sampling Techniques: Purposive sampling and simple random sampling techniques were used to select the respondents. The population comprises 200 respondents in Ekiti State University, Ado Ekiti. All the respondents have access to social media platforms, and were able to contribute to debates on social media on virtually all democratic discourse on social media platforms. Such discourse include corruption, terrorism, insurgency, economic mismanagement and ethnic and religious nepotism

Table1: Age of Respondents in relation to political discourse and social media usage

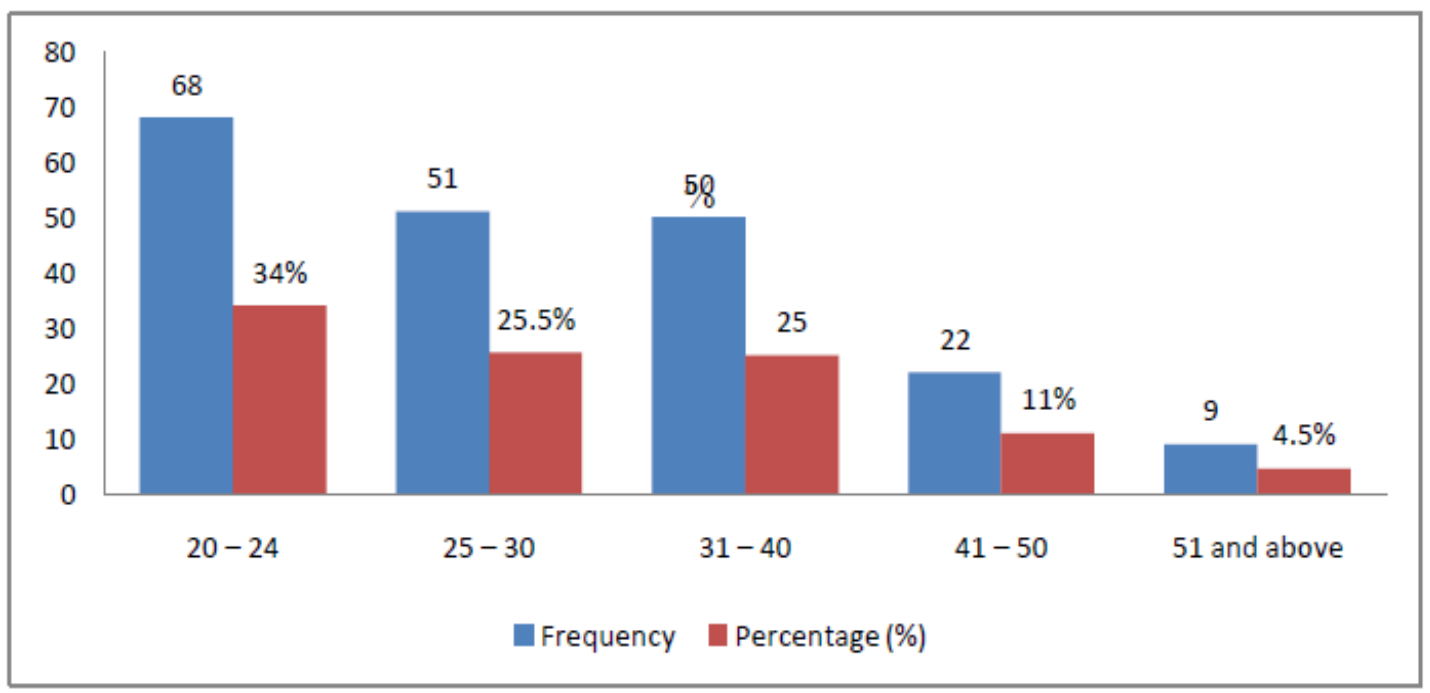

(Source: Field Study)

Table 1 shows that $34 \%$ of the respondents were between $20-24$ years old, $25 \%$ were between 31 40years old, $11 \%$ were between $41-50$ years old and $4.5 \%$ of the respondents were at least 51 years old. The data rightly shows that the respondents are neither too young nor too old to be involved in political discourse on social media platforms in Nigeria.

Table2: Classification of Social Media Platform

\begin{tabular}{|l|l|l|}
\hline & Frequency & \multicolumn{1}{|c|}{ Percentage (\%) } \\
\hline Collaborative Projects e.g. Wikipedia & 27 & 13.5 \\
\hline Blogs e.g. Linda Ikeji Blog & 19 & 9.5 \\
\hline Content Communities e.g. Youtube & 32 & 16.0 \\
\hline Social Networking Sites e.g. Facebook and Twitter & 74 & 37.0 \\
\hline Mobile Instant Messaging e.g. Whatsapp, BBM & 48 & 24.0 \\
\hline Total & 200 & 100.0 \\
\hline
\end{tabular}

(Source: Field Study)

Table 2 shows the classification of social media platforms where respondents pass and receive information. $13.5 \%$ of the respondents used Collaborative Projects to source for information, 9.5\% used Blogs, 16\% used Content Communities, 37\% used Social Networking Sites, and 24\% used Mobile Instant Messaging to source for information. 
Table3: Respondents Access to Information on Social Media

\begin{tabular}{|l|l|l|}
\hline & Frequency & Percentage (\%) \\
\hline Yes & 161 & 80.5 \\
\hline No & 39 & 19.5 \\
\hline Total & 200 & 100.0 \\
\hline
\end{tabular}

(Source: Field Study)

Table 3 shows that $80.5 \%$ of the respondents got adequate information from social media and $19.5 \%$ of the respondents did not get adequate information from social media platforms

Table4: Respondents Appraisal of Social Media Roles in Nigerian Democratic governance

\begin{tabular}{|c|c|c|c|c|c|c|}
\hline $\mathbf{S} / \mathbf{N}$ & & $\begin{array}{c}\text { SA } \\
\mathbf{N}(\%)\end{array}$ & $\begin{array}{l}\mathbf{A} \\
\mathbf{N}(\%)\end{array}$ & $\begin{array}{l}\mathrm{U} \\
\mathbf{N}(\%)\end{array}$ & $\begin{array}{l}\mathbf{D} \\
\mathbf{N}(\%)\end{array}$ & $\begin{array}{l}\text { SD } \\
\mathbf{N}(\%)\end{array}$ \\
\hline \multicolumn{7}{|c|}{ ANALYSIS OF RESEARCH QUESTION ONE } \\
\hline 1 & $\begin{array}{l}\text { Social media are excessively hostile } \\
\text { to Nigerian political leaders }\end{array}$ & $63(31.5)$ & $105(52.5)$ & $15(7.5)$ & $16(8.0)$ & $1(0.5)$ \\
\hline 2 & $\begin{array}{l}\text { Social media are impacting } \\
\text { positively on democratic rule in } \\
\text { Nigeria }\end{array}$ & $101(50.5)$ & $89(44.5)$ & $0(0.0)$ & $10(5.0)$ & $0(0.0)$ \\
\hline 3 & $\begin{array}{lll}\text { Social media are a blessing } & \text { to } \\
\text { information management } & \text { in } \\
\text { Nigeria's democratic rule } & \\
\end{array}$ & $146(73.0)$ & $54(27.0)$ & $0(0.0)$ & $0(0.0)$ & $0(0.0)$ \\
\hline \multicolumn{7}{|c|}{ ANALYSIS OF RESEARCH QUESTION TWO } \\
\hline 4 & $\begin{array}{l}\text { Social media break the information } \\
\text { barrier between the government and } \\
\text { the governed }\end{array}$ & $66(33.0)$ & $71(35.5)$ & $10(5.0)$ & $11(5.5)$ & $42(21.0)$ \\
\hline 5 & $\begin{array}{l}\text { Issues discussed on social media } \\
\text { about Nigerian political leaders are } \\
\text { often false }\end{array}$ & $64(32.0)$ & $91(45.5)$ & $9(4.5)$ & $25(12.5)$ & $11(5.5)$ \\
\hline 6 & $\begin{array}{l}\text { Social media is a platform for } \\
\text { political vendetta }\end{array}$ & $43(21.5)$ & $29(14.5)$ & $35(17.5)$ & $47(23.5)$ & $46(23.0)$ \\
\hline
\end{tabular}

(Source: Field Study, )

\section{DISCUSSION OF FINDINGS}

Research Question one: What role has social media played in sustaining democracy in Nigeria?

The researcher asked the respondents this question to know the level of involvement of social media in helping to sustain democratic governance in Nigeria. The responses of the respondents to this question was analyzed and presented in table 4 above. Data on the Table indicate that $84 \%$ of the respondents agreed that social media are excessively hostile to Nigerian political leaders. Table 4 also shows that $95 \%$ of respondents agreed that social media are impacting positively on democratic governance in Nigeria. The respondents also believe that social media are a blessing to information management under democratic governance in Nigeria. It can thus be said that the social media have been playing a good and positive roles in sustaining democracy in Nigeria though it can be very hostile in doing so at times. The hostility to some political leaders is usually borne out of the excess of the politicians who are known to be dubious in character and not sincere in their political activities in governance

Research Question two: Does the social media criticism of the government have any effect on democratic governance in Nigeria?

In order to know if criticisms on social media have any effect on democratic governance in Nigeria, some questions were asked by the researchers and answered by the respondents. These answers were analyzed and also presented in table 4 above. Table 4.made us to know that majority of the respondents $(90 \%)$ agreed that social media break the information barriers between the government and the governed. Table 4 also shows majority of respondents $(80 \%)$ agreeing that some issues discussed on social media about political leaders are often false. The Table shows us that more respondents $(46 \%)$ do not believe that the social media are a place for political vendetta. It can thus be concluded that the social media as a platform for criticizing government have more of a balanced effect on democratic governance in Nigeria. 
These findings show that social media are very important in the success of democracy in Nigeria. It also depicts that social media brings both the government and the governed closer to each other than they could ever imagine. They are vital platforms for the expression of one's self for a proper practice of democracy in Nigeria and their importance has been increasing significantly over the years.

It also shows that though social media might be a blessing to information dissemination under democratic rule in Nigeria, if not properly managed (checked and monitored) they could cause doom. However, the result of this research work also reveals that social media has so many advantages on information management and democratic rule in Nigeria and a little disadvantages.

\section{CONCLUSION}

The findings derived from the analysis above gave way to the following conclusions:

- Social media platforms are sources of credible information.

- Social media influence positively on democratic rule in Nigeria.

- Social media are a blessing to information management in Nigeria's democratic rule.

- Some comments on Social media are excessively hostile to Nigerian political leaders, but all with a view to impressing on Nigerian political leaders to do the right thing to enhance a durable democracy

- Social media platforms are a free for all avenue to accuse political opponents of wrong doings, however such accusations often times generate positive reactions from political office holders to be upright in governance

- Some issues discussed on social media about Nigerian political leaders are often false..and in most cases to provoke them to react and correct any wrong insinuations about their style of governance

\section{RECOMMENDATIONS}

As a result of the findings based on data analysis of the issues at stake in the study the following recommendations are made

- Since there is no gate keeping device like in the traditional media of print and broadcast, there should be some level of control on the use of social media to prevent abuse of the Press Freedom by those who post materials on social media platforms

- Efforts should be made to harness a lot of the positive materials on social media for effective governance and to entrench a durable democracy in Nigeria

- Political office holders should be made to respond at an open forum at least once a month to some grave allegations often leveled against them on the platforms of social media

- Attempts must be made to get authors of some serious allegations against political office holders to substantiate them at an open forum where all the service providers, political office holders and authors of materials on social media will be present to face each other and trash out issues bothering on good governance in Nigeria

- Further studies should be carried out on how the use of social media can be encouraged by all and sundry to allow healthy and more positive discussions about good governance in Nigeria's political arena.

\section{REFERENCES}

[1] Aborisade,O. (2012). The Citizen Reporters, How Technology Transforms News Gathering, Reporting and Distribution; Lambert Academic Publishing.

[2] Al-nuaimy, W., Zhang, J. \& Noble, A. (2001).Web-based learning Environment for a communications module.Computer Applications in engineeringEducation9, 2,114 121.

[3] Anaeto, S.G., Onabajo, S.O. and Osifeso, J.B. (2008).Models and Theories of Communication.

[4] Baran, S.T. and Davis (2000). Mass communication theory: Foundations, formats and future. Wadsworth Thomas Learning. 
[5] Flew,T.(2008). New media: An introduction. Melbourne, Australia: Oxford University Press.

[6] Gillmor, D. (2004). We the media: Grassroots journalism by the pople, for the people. Sebastopol,CA: O'Reilly.

[7] Jacobs, B. (2013). The Role of the Social Media in Sustaining Democratic Governance in Nigeria. Journal of Management Skills and Techniques, 4(1): 1-11

[8] Jost, K.,\&Hipolit, M.J. (2006).Blog explosion.Retrieved May 28, 2016 from CQ Researcher Online.

[9] Kietzmann, J.H, Hermkens, K., McCarthy, I. \& Silvestre, B.S. (2011).Social media? Get serious! Understanding the functional building blocks of social media. Business Horizons, 54(3): 241-251

[10] Marshall, J. (2005). Citizen journalism continues to surge. The Quill, 93(8), 14

[11] Oxford Dictionary 2011a, Oxford Dictionaries, Oxford, UK. Retrieved 12 May 2016 from http://oxforddictionaries.com/definition/social+media.

[12] Oxford Dictionary 2011b, Oxford Dictionaries, Oxford, UK. Retrieved 12 May 2016 from http://oxforddictionaries.com/definition/social+networking.

Citation: BABALEYE, Taye, et al. "Influence of Social Media on Democratic Governance in Nigeria". International Journal of Media, Journalism and Mass Communications (IJMJMC), vol 6, no. 1, 2020, pp. 1320 doi: http://dx.doi.org/10.20431/2454-9479.0601002

Copyright: (C) 2020 Authors. This is an open-access article distributed under the terms of the Creative Commons Attribution License, which permits unrestricted use, distribution, and reproduction in any medium, provided the original author and source are credited. 